\title{
MENYUSUN LAPORAN KEUANGAN
}

Makalah Ini Disusun untuk Memenuhi Tugas Individual pada Mata Kuliah Kewirausahaan

Dosen Pengampuh : Ibu Dra. Hj. Nuraeni Gani, MM

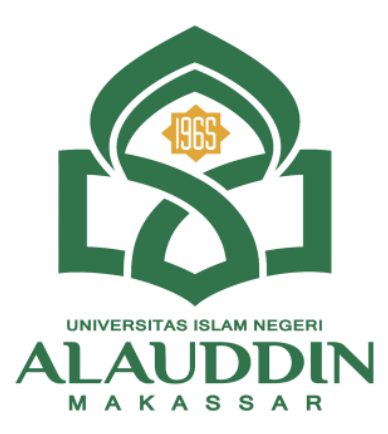

Disusun oleh :

EVI SUGIATNI

90500120103

sugiatnieviee2001@gmail.com

\author{
PERBANKAN SYARIAH \\ FAKULTAS EKONOMI DAN BISNIS \\ UNIVERSITAS ISLAM NEGERI MAKASSAR \\ TAHUN 2021
}




\section{KATA PENGANTAR}

Puji syukur kehadirat Allah SWT yang telah memberikan rahmat dan hidayah-Nya sehingga Saya dapat menyelesaikan tugas makalah yang berjudul "BISNIS KULINER CIMOL" ini tepat pada waktunya. Adapun tujuan dari penulisan dari makalah ini adalah untuk memenuhi tugas dosen pada mata kuliah Kewirausahaan. Selain itu, makalah ini juga bertujuan untuk menambah wawasan tentang Kewirausahaan di tinjau dari BISNIS KULINER CIMOL bagi para pembaca dan terutama bagi penulisnya.

Kami mengucapkan terima kasih kepada Ibu Dra. Hj. Nuraeni Gani, MM selaku Dosen Pengampu Mata Kuliah Kewirausahaan yang telah memberikan tugas ini sehingga dapat menambah pengetahuan dan wawasan Kami sesuai dengan bidang studi yang kami tekuni. Kami juga berterima kasih kepada Pihak-pihak yang telah membantu kami dalam meyusun makalah ini dan juga telah membagi sebagian pengetahunnya sehingga kami dapat menyelesaikan makalah ini.

Kami menyadari, makalah yang kami tulis masih jauh dari kata sempurna. Oleh karena itu, kritik dan saran yang membangun sangat kami nantikan demi kesempurnaan makalah ini.

Gowa, 20 Desember 2021

Penulis

Evi sugiatni 


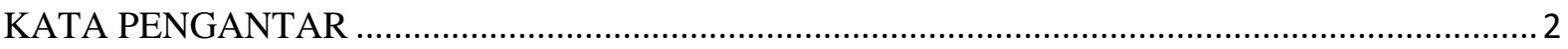

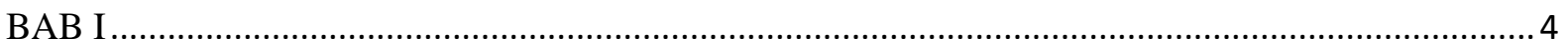

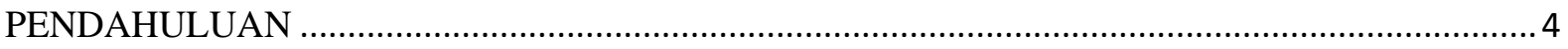

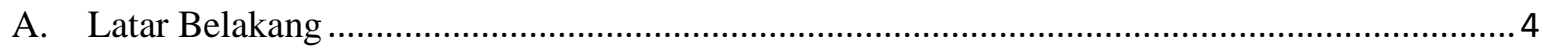

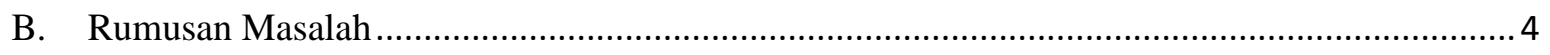

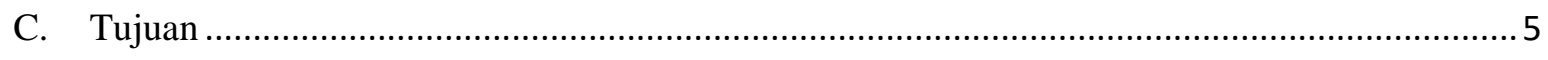

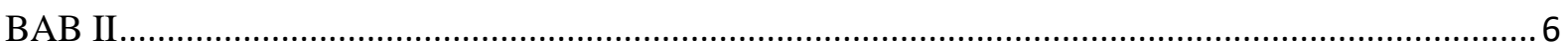

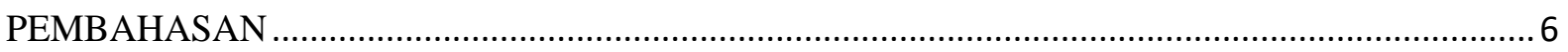

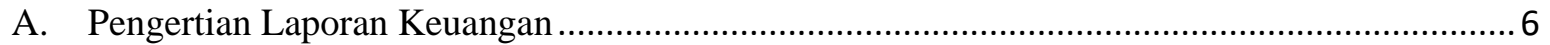

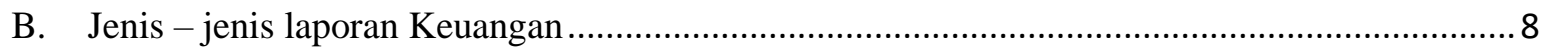

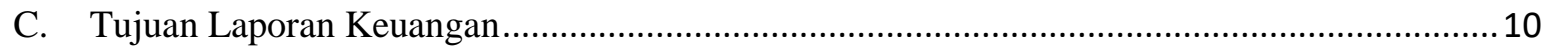

D. Sistematika Penyusunan Laporan Keuangan ................................................................... 10

E. Bentuk-bentuk Laporan keuangan ............................................................................. 11

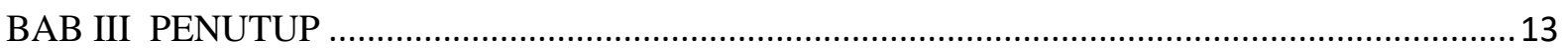

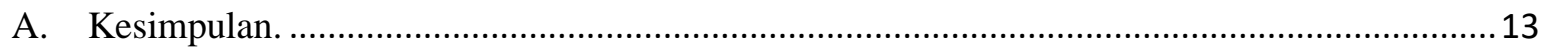

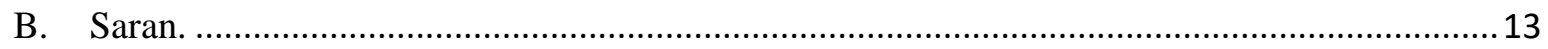

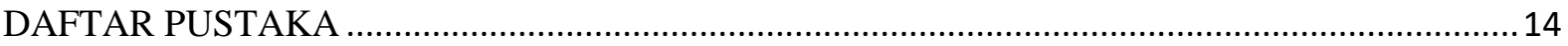




\section{BAB I \\ PENDAHULUAN}

\section{A. Latar Belakang}

Negara Indonesia adalah suatu negara berkembang yang tidak dapat terpisahkan oleh kegiatan yang berkaitandengan usaha baik usaha itu usaha yang kecil atau usaha menengah ( UMKM). Tentu setiap perusahaan yang memiliki bisnis perluh untuk memiliki neraca keuangan ats peusahaannya bahkan perluh untuk menganalisis kinerja keuangan yang dimiliki. Tingginya potensi yang dimiliki oleh UMKM dalam hal pengembangan ekonomi sehingga hal itu tidak lagi seimbang dengan kualitas yang dimiliki UMKM. Dalam UMKM standar laporan keuangannya pada usaha mikro bertujuan untuk menyediakan sebuah informasi yang berkaitan dengan posisi keuangan, kinerja, dan perubahan posisi keuangan. Laporan keuangan yang bersifat andal serta yang efektif sebenarnya sangat penting bagi usaha yang bergerak di UKM karena akses yang mereka miliki terbatas, akses terbatasa itu adalah akses untuk mengelolah sumber daya keuangan. Karena keputusan yang buruk justru akan sangat berpengaruh buruk terhadap usaha kita, pengaruh yang disebabkan sangat cepat dapat menyebabkan terjadinya likuiditas.

Pada dasarnya, tujuan utama dari suatu entitas sebuah bisnis merupakan untuk meningkatkan nilai entitas itu sendiri. Peningkatan suatu nilai entitas haruslah selalu di barengi dengan peningkatan kinerja perusahaan juga. Salah satu aspek yang dapat dilihat dalam hal ini adalah penilaian terhadap kinerja adalah peningkatan penjualannya. Sebuah teori yang berasal dari teori keuangan tradisonal berasumsi bahwa sebuah informasi, baik itu informasi keuangan sebenarnya tersedia secara bebas dan sangat luas, serta akurat dan cepat dalam transmisikanya. Laporan keuangan senantiasa selalu mewakili sumber informasi yang kuat dan pasti relavan. Informasi yang ada di dalam laporan keuangan merupakan sebuah data yang akan diperlukan yang bertujuan untuk menginformasikan sebuah hasil analisis yang akurat dan penting bagi pemilik perusahaan, investor atau bahkan bagi pemberi pinjaman.

Suatu perusahaan akan di katakan sebagai sebuah perusahaan yang efektif dan efesien jika perusahaan itu telah menerapkan sistem penyusunan laporan keuangannya yang pastinya sudah sesuai dengan berbagai prosedur dan langkah-angkah yang ada di dalam akuntansi. Jika perkembangan kegiatan operasional berjalan dengan kompleks atau lengkap naka perlu untuk membuat penyusunan laporannya karena laporan keuangan akan bertujuan untuk menunjukkan beberapa kondisi keuangan yang dimiliki oleh suatu perusahaan.

B. Rumusan Masalah

1. Apa itu laporan keuangan?

2. Berapa jenis laporan keuangan yang di dapat digunakan ?

3. Apa tujuan laporan keuangan

4. Bagaimana sistemasika penyusunan laporan keuangan ? 
5. Apa saja bentuk-bentuk laporan keuangan ?

C. Tujuan

1. Memahami pengertian Laporan keuangan

2. Menganalisis jenis laporan keuangan

3. Mengidentifikasi tujuan Laporan Keuangan

4. Memahami penyusunan laporan Keuangan

5. Menganalisis bentuk-bentuk laporan keuangan 


\section{BAB II \\ PEMBAHASAN}

A. Pengertian Laporan Keuangan

Secara umum yang kita ketahui mengenai laporan keuangan adalah sebuah laporan yang di dalamnya berisi tentang pencatatan uang dan juga seluruh transaksi yang terjadi dalam bisnis, baik itu transaksi pembelian ataupun transaksi penjualan atau bahkan trnsaksi yang lain yang di dalamnya memiliki nilai ekonomi dan juga nilai moneter. Biasanya laporan ini selalu di susun pada periode tertentu. Seluruh ketentuan di dalam laporan akan ditentukan oleh sebuah perusahaan apakah laporan perusahaan akan dibuat pada setiap bulan atau dibuat pada setiap satu tahun sekali, tapi terkadang ada perusahaan yang menggunakan kedua hal tersebut atas beberapa pertimbangan dari perusahaan itu sendiri. Laporan keuangan ini di susun dengan tujuan untuk mengetahui suatu kondisi yaitu kondisi finansial sebuah perusahaan secara menyeluruh. Sehingga para stakeholder dan juga para pengguna informasi akuntansi dapat melakukan sebuah kegiatan yaitu kegiatan evaluasi dan pencegahan dengan tepat dan juga cepat apabila kondisi keuangan sebuah usaha sedang mengalami masalah atau kendala.

Mengingat seberapa pentinnya hal itu, sehingga laporan ini wajib disusun dengan tepat, cermat dan juga dibutuhkan sebuah pertanggungjawaban yang besar yang akan diserahkan secara mutlak kepada orang yang memiliki kompeten di bidangnya, yaitu kepada seorang akuntan perusahaan. Para akuntan yang dimiliki setiap perusahaan harus mempersentasikan laporan yang telah mereka susun dengan detail di depan para stakeholder yang dimana stakeholder ini dilakukan ketika melakukan evaluasi kinerja keuangan secara tahunan.

Laporan keuangan sebenarnya merupakan sebuah informasi terkait dengan keuangan pada perusahaan yang dapat digunakan untuk melihat sebuah kondisi di dalam perusahaan dan dapat menilai kinerja perusahaan dalam suatu periode tertentu. Laporan keuangan bagi suatu perusahan digunakan hanya untuk sebagai sarana evaluasi dari sebuah pekerjaan yang dilakukan oleh para akuntan perusahaan, akan tetapi tahap selanjutnya laporan keuangan justru tidak hanya sebagai sarana evaluasi akan tetapi juga sebagai sebuah dasar untuk mennetukan atau menilai suatu posisi keuangan yang dimiliki oleh perusahaan. Laporan keuangan dapat juga di susun dengan tujuan sebagai laporan keuangan yang ingin ditujukan kepada perpajakan, regulator lain yang dimana tertuju pada Bank Indonesia, Depertemen keuangan atau bahkan untuk manajemen perusahaan.

Laporan keuangan ini dapat menyimpulkan sebuah kondisi keuangan dan hasil dari usaha yang ada di dalam suatu perusahaan pada waktu yang tertentu. Adapun pihak-pihak yang berkepentingan atas laporan keuangan. Dalam hal ini pihak-pihak tersebut memerlukan laporan keuangan dengan tujuan untuk memutuskan beberapa keputusan di dalam perusahaan. Diantara syarat-syarat yang harus dipenuhi para akuntan dalam menyusun laporan keuangan yaitu laporan keuangan yang dibuat harus mengandung sebuah kejelasan faktadan kelengkapan data serta informasi yang akan dilaporkan oleh pihak akuntan perusahaan. Karena setiap komponen yang ada di dalam laporan keuangan harus terdeksripsikan dengan baik, jelas dan lengkap. 
1. Pihak-pihak yang berkepentingan

Pentingnya Informasi akuntansi dalam sebuah perusahaan untuk digunakan sejumlah pihak. Para pemakai informasi akuntansi ini memiliki tujuan yang berbeda tergantung pada kebutuhan mereka. Oleh karena itu, sistem informasi akuntansi dari perusahaan bisnis harus dirancang dengan cara yang sesuai standar akuntansi dan menghasilkan laporan untuk memenuhi kepentingan semua semua pihak pemakai informasi akuntansi. ${ }^{1}$

1) Pemakai informasi akuntansi internal.

- Manajemen

Manajemen menggunakan informasi akuntansi untuk mengevaluasi dan menganalisis kinerja dan posisi keuangan organisasi, untuk mengambil keputusan penting dan tindakan yang tepat untuk meningkatkan kinerja bisnis dalam hal profitabilitas, posisi keuangan dan arus kas. Salah satu peran utama manajemen adalah menetapkan aturan dan prosedur untuk mencapai tujuan organisasi. Untuk tujuan ini, manajemen menggunakan informasi yang dihasilkan oleh sistem manajemen keuangan organisasi. ${ }^{2}$

- Pemilik

Pemiliki menginvestasikan modal dengan tujuan untuk memulai dan melaksanakan suatu bisnis dengan tujuan utamanaya yaitu untuk memperoleh laba. Mereka akan memerlukan sebuah informasi yang akurat yang akan digunakan sebagai sebuah alat untuk mengetahui apa yang telah mereka dapatkan atau yang hilang selama beberapa waktu dalam satu tahun periode.

2) Pemakai informasi akuntansi eksternal.

- Investor

Investor merupakan salah satu pemakai informasi akuntansi yang aktual dan berpontesial. Informasi akuntansi ini digunakan untuk mengetahui bagaimana dana yang ada di dalam perusahaan digunakan dengan baik dan apa saja yang sedang diharapkan dari seluruh kinerja bisnisnya di masa yang akan datang dalam hal ini berkaitan dengan profitabilitas dan pertumbuhan.

- Kreditor

\footnotetext{
${ }^{1}$ https://cpssoft.com/blog/akuntansi/siapa-saja-pemakai-informasi-akuntansi/

${ }^{2}$ https://cpssoft.com/blog/akuntansi/siapa-saja-pemakai-informasi-akuntansi/
} 
Kreditor atau pemberi sebuah pinjaman merupakan individu atau sebuah lembaga keuangan yang biasa dijadikan sebagai tempat pinjaman dana dan mendapatkan keberhasilan bunga atas pinjaman yang di berikan.

- Pemasok

Pemasok merupakan pengguna yang ketiga yang dimana pemasok ini merupakan individu atau sebuah organisasi bisnis yang biasa menjual bahan mentah ke bisnis lain yang biasa menggunakan metode kredit.

- Pelanggan

Informasi akuntansi juga berdampak begitu penting terhadap para pelanggan sebuah perusahaan. Para pelanggan anda pasti ingin mengetahui beberapa hal mengenai perusahaan yaitu seperti posisi bisnis kita.

2. Landasan laporan keuangan

Laporan keuangan juga memiliki landasan yang disebutkan dalam al-Qur'an yaitu QS. Al-Anbiyaa : 47.

Terjemahnya : "kami akan memasang timbangan yang tepat pada hari kiamat, maka tiadalah dirugikan seseorang barang sedikitpun. Dan jika (amalan itu) hanya seberat biji sawi pun pasti kami mendatangkan( pahalanya). Dan Cukuplah kami sebagai pembuat perhitungan.

B. Jenis - jenis laporan Keuangan

Berdasarkan sebuah penyataan yang ada di dalam Pernyataan Standar Akuntansi Keuangan 1 (2015), Bahawa komponen keuangan yang harus atau yang lengkap itu adalah sebagai berikut :

1. Laporan Laba rugi

Laporan keuangan pertama yang paling utama yang harus diperhatikan untuk sebuah perusahaan adalah laba rugi. Karena jika kita menginginkan informasi yang mudah dari dalam perusahaan atau kondisi yang sedang terjadi di dalam perusahaan maka kita harus memperbaiki laporan laba rugi perusahaan. Laporan laba rugi ini juga bisa digunakan dalam hal tersebut. Laporan laba rugi berkaitan dengan informasi tentang kondisi perusahaan pada periode akuntansi tersebut. 
Apakah perusahaan mendapatkan keuntungan atau justru mengalami kerugian di dalmnya. Karena, laporan laba rugi di dalamnya terkandung sebuah informasi pendapatan dan beberapa biaya yang akan dikeluarkan oleh setiap perusahaan. Maka kita sudah tidak asing lagi dengan laporan laba rugi ini karena laporan laba rugi ini memang memiliki peran yang sangat penting untuk setiap perusahaan.

2. Laporan perubahan modal.

Jenis laporan keuangan yang satu ini akan memberikan sebuah informasi yang berupa penambahan modal yang dimiliki oleh setiap perusahaan setelah melakukan kegiatan bisnisnya di dalam perusahannya. Terdapat keterkaitan antara laporan perubahan modal dengan laporan laba rugi perusahaan tersebut. Hal ini dikarenakan umumnya modal yang akan mengalami penambahan pada saat perubahan akan mendapatkan keuntungan. Beberapa hal informasi yang akan di cantumkan di dalam laporan perubahan modal yaitu di antaranya jumlah modal awal pada saat memulai operasional, Priva, laba atau rugi, dan deviden yang dapat dibagikan. Itulah mengapa, laporan perubahan ini sangat dibutuhkan oleh para investor yang akan menanamkan beberapa modal ke dalam suatu perusahaan.

3. Neraca

Pada jenis laporan ini merupakan jenis laporan neraca. Di dalam jenis laporan ini yaitu laporan neraca, akan terdapat beberapa informasi yang berkaitan dengan aktiva dan juga pasiva yang juga pasti dimiliki oleh setiap perusahaan. Demikian itu pula, modal yang dimiliki oleh setiap perusahaan yang memiliki bisnis yang sedang berjalan juga akan tercatat di dalam laporan jenis ini yaitu laporan neraca. Sehingga, pada dasarnya neraca ( balance sheet) adalah sebuah laporan yang berisikan tentang tiga komponen utama yaitu aset, ekuitas dan kewajiban.

4. Laporan arus kas

Jenis laporan keuangan ini merupakan jenis laporan yang biasa dikenal sebagai laporan arus kas. Hal ini adalah salah satu dari seluruh informasi yang berkaitan dengan aliran arus kas yang masuk, maupun aliran kas yang keluar dari sebuah perusahaan dan itu terjadi dalam periode akuntansi itu sendiri. Adanya laporan arus kas ini maka akan dapat diketahui seberapa tingkat operasional serta beberapa aktivitas keuangan yang akan di alami oleh perusahaan.

Laporan ini juga dapat dijadikan sebagai sebuah acuan untuk memperkirakan berapa jumlah aliran uang yang secara tunai yang akan diterima oleh perusahaan pada setiap periode akuntansi perusahaannya. Selain dari itu juga, Investor juga sebenarnya dapat memanfaatkan jenis laporan ini dikarenakan investor dapat mengetahui beberapa efektivitas langkah keuangan yang akan diambil oleh perusahaan yang akan di tanamkan dana atau modal.

5. Catatan Laporan 
Dalam laporan ini tau jenis laporan keuangan yang terakhir dan juga merupakan laporan yang sangat penting bagi perusahaan yaitu catatn laporan. Catatan ini akan memberikan sebuah gambaran secara lebih detail tentang apa yang akan dicantumkan di dalam laporan keuangan yang lain. Melalui jenis laporan yang satu ini, baik dari pimpinan maupun dari pihak investor dapat mengetahuipenyebab dari suatu kendala yang akan dihadapi dalam operasionalnya.

C. Tujuan Laporan Keuangan

Pembuatan laporan keuangan ini yaitu sebagai sumber untuk memberikan sebuah informasi yang berkaitan dengan beberapa hal yaitu posisi keuangan perusahaan, kinerja keuangan, dan arus kas entitas yang bermanfaat bagi sebagian besar para pengguna laporan keuangan dalam peyusunan keputusan ekonomi.

D. Sistematika Penyusunan Laporan Keuangan

Pada tahap ini tentunya membutuhkan beberapa tahap dalam penyusunan laporan keuangan yaitu diantarayanya yaitu sebagai berikut:

1. Mengumpulkan dan mencatat transaksi pada jurnal

Transaksi adalah sebuah kegiatan umum yang juga sering dilakukan oleh setiap perusahan, baik itu dalam transaksi pembelian, penjualan, penukaran barang, sewa ataupun transaksi yang lainnya. Biasanya bukti transaksi ini juga merupakan suatu hal yang sangat penting, sesuatu hal yang utama dalam laporan akuntansi sehingga bukti transaksi tidak dapat hilang. Bukti transaksi juga merupakan sebuah dasar pencatatan dalam membuat laporan keuangan.

2. Memposting jurnal ke dalam buku besar

Setelah membuat jurnal maka langkah kedua yaitu jurnal yang telah dibuat akan segera di posting ke dalam buku besar. Buku besar adalah sebuah rincian dari setiap akun-akun yang ada di dalam. Maka tidak sulit untuk melaksanakan hal ini, hanya tinggal memindahkan beberapa transaksi yang telah dicatat dalam jurnal ke akun-akun yang tepat dengan detail.

3. Menyusun neraca saldo

Neraca saldo merupakan sebuah daftar rekening-rekening buku besar dengan saldo atau kredit. Maka langkah selanjutnya setelah menyusun laporan buku besar yaitu menyusun neraca saldo. Kemudian daftar rekening pada buku besar dikelompokkan ke dalam kelompok yang lebih dikenal sebagai kelompok pasiva atau juga dikelompokkan ke dalam kelompok aktiva.

4. Kumpulkan data untuk membuat jurnal penyesuian 
Pada tahap ini akan dilakukan penjurnalan ulang karena ada Beberapa transaksi yang mungkin ada yang belum tercatat atau transaksi terjadi di akhir saat tahap penyusunan laporan keuangan dan masih ada yang tidak sesuai dengan keadaan yang ada di akhir periode, sehingga data tersebut dikumpulkan untuk membuat jurnal penyesuaian.

5. Menyusun neraca lajur.

Untuk memudahkan penyusunan laporan keuangan maka dari itu kita memerlukan untuk menyusun neraca lajur atau kertas kerja yang dimulai dari data yang ada neraca saldo dan disesuaikan dengan data yang diperoleh dari jurnal penyesuaian. Selanjutnya, saldo yang sudah disesuaikan akan terlihat padakolom neracasaldo yang telah disesuaikandanmerupakansaldo-saldo yang akan dilaporkan dalam neraca dan laporan rugi laba.

6. Membuat laporan keuangan

Cara selanjutnya yang dapat dilakukan membuat laporan keuangan sederhana sesuai dengan alur dan urutan adalah laporan yang sudah di buat di neraca lajur tinggal di tulis dengan rapi sesuai ketentuan atau standar laporan keuangan. Hal ini karena dalam neraca lajur sudah dipisahkan jumlah-jumlah yang dilaporkan dalam neraca atau laporan rugi laba. Informasi yang disajikan dalam laporan keuangan sangat penting, karena mencerminkan kinerja perusahaan dan dapat digunakan untuk pengambilan keputusan.

E. Bentuk-bentuk Laporan keuangan

1. Neraca

Neraca merupakan salah satu laporan yang terpenting bagi perusahaan setiap perusahaan diharuskan untuk menyajikan laporan keuangan dalam bentuk neraca. Neraca adalah laporan yang sistematis tentang aktiva, kewajiban, dan ekuitas dari perusahaan pada suatu saat tertentu ${ }^{3}$.

1) Aktiva (Asset)

Menurut Ikatan Akuntansi Indonesia (2002:13) dalam buku Standar Akuntansi Keuangan dijelaskan bahwa "Aktiva adalah sumber daya yang dikuasai oleh pemerintah sebagai akibat dari peristiwa masa lalu dan dari mana manfaat ekonomi di masa depan diharapkan akan diperoleh perusahaan".Lebih tegas lagi bahwa pengertian aktiva tidak terbatas pada kekayaan perusahaan saja, tetapi juga termasuk pengeluaran-pengeluaran yang belum dialokasikan (deffered charges) atau biaya yang masih harus dialokasikan pada penghasilan yang akan datang, serta aktiva yang tidak

\footnotetext{
${ }^{3}$ Eliza,S. Akun, "Analisa Rasio Laporan Keuangan Pada Pt. Jasa Sarana Citra Bestari Cabang Bengkalis Menurut Perspektif Isla”. Laporan Keuangan.
} 
berwujud lainnya (intangable asset) misalnya goodwill, hak paten, hak menerbitkan dan sebagainya ${ }^{4}$.

2) Kewajiban.

Kewajiban adalah sebuah hutang perusahaan yang ada pada saat ini yang timbul karena peristiwa masa lalu, Penyelesaikannya diharapkan mengakibatan sebuah arus keluar dari sumber daya dari perusahaan yang mengandung manfaat ekonomi. Hutang atau kewajiban perusahaan dapat dibedakan ke dalam hutang lancar (hutang jangka pendek) dan hutang jangka panjang (Munawir,2004:18). ${ }^{5}$

3) Modal (Equity/Net Worth)

Modal merupakan hak atau bagian yang dimiliki Perusahaan yang ditunjukkan dalam pos modal (modal saham), surplus dan laba yang ditahan (Munawir,2004:19). Atau bisa juga dikatakan bahwa modal adalah hak residual atas aktiva perusahaan setelah dikurangi semua kewajiban (Ikatan Akuntansi Indonesia,2002:13). ${ }^{6}$

2. Laporan Laba - Rugi

Laporan Laba-Rugi (Income statement), Penghasilan bersih (laba) seringkali digunakan sebagai ukuran kinerja atau sebagai dasar bagi ukuran yang lain seperti imbalan investasi (return on investment) atau penghasilan perlembar saham (earning per share). Unsur yang langsung berkaitan dengan pengukuran penghasilan bersih (laba) adalah penghasilan dan beban. ${ }^{7}$

\footnotetext{
${ }^{4}$ Software Keuangan. Bentuk-Bentuk Laporan. (https://softwarelaporankeuangan.com/bentuk-bentuklaporan-keuangan.html, 24 Desember 2021. 1:34. )

${ }^{5}$ Software Keuangan. Bentuk-Bentuk Laporan. (https://softwarelaporankeuangan.com/bentuk-bentuklaporan-keuangan.html, 24 Desember 2021. 1:34. )

${ }^{6}$ Software Keuangan. Bentuk-Bentuk Laporan. (https://softwarelaporankeuangan.com/bentuk-bentuklaporan-keuangan.html, 24 Desember 2021. 1:34. )

${ }^{7}$ Eliza,S. Akun, “Analisa Rasio Laporan Keuangan Pada Pt. Jasa Sarana Citra Bestari Cabang Bengkalis Menurut Perspektif Isla". Laporan Keuangan.
} 


\section{BAB III \\ PENUTUP}

A. Kesimpulan.

Laporan keuangan merupakan salah satu bentuk pertanggung jawaban perusahaan kepada para pemangku kepentingannya. Laporan keuangan adalah catatan informasi keuangan suatu entitas yang dapat menggambarkan kinerja entitas tersebut pada suatu periode akuntansi. Laporan keuangan dibuat untuk menyajikan informasi mengenai kinerja perusahaan dan berguna untuk mengambil keputusan bisnis. Selain itu, laporan keuangan juga menunjukan bentuk transparansi dan akuntabilitas perusahaan/entitas/organisasi kepada masyarakat. Laporan keuangan perusahaan dibuat setiap akhir periodeakuntansi.Setiapperusahaanmemilikiperiodeakuntansiyangberbeda-beda. Bisa selama 1 tahun, ataupun per 6 bulan tergantung kepada kebijakan tiap perusahaan

B. Saran.

Untuk melengkapai dan meyempurnakan makalah selanjtknya saya sebagai penulis mengharapkan kritik dan saran yang mendukung untuk menyempurnakan makalah saya baik makalah ini ataupun makalah selajutnya. 


\section{DAFTAR PUSTAKA}

Aminatul Mutiah, R. (2019). Penerapan Penyusunan Laporan Keuangan pada UMKM Berbasis SAK EMKM. Laporan Keuangan, 3(3), 223-229.

Ardiansyah, T. (2020). Pola Laporan Keuangan wirausahawan di Indonesia. Laporan Keuangan, 4(3), 286-300.

Eliza, S. A. (2020). ANALISA RASIO LAPORAN KEUANGAN PADA PT. JASA SARANA CITRA BESTARI CABANG BENGKALIS MENURUT PERSPEKTIF ISLAM. Laporan Keuangan , 56-76.

Komaludina, A. \&. (2017). ANALISIS KEMAMPUAN MENYUSUN LAPORAN KEUANGAN, KEMAMPUAN MANAJERIAL, JIWA KEWIRAUSAHAAN DAN MOTIVASI SEBAGAI FAKTOR PENENTU KINERJA OPERASIONAL. Laporan Keuangan, 3(2), 104-113.

Pongoh, M. (2013). ANALISIS LAPORAN KEUANGAN UNTUK MENILAI KINERJA KEUANGAN PT. BUMI RESOURCES TBK. Laporan Keuangan, 1(3), 669-679.

Pratama Putra, D. (2018). Pengaruh Kemampuan Aparatur, Pemanfaatan Sistem Informasi Akuntansi Keuangan Daerah, dan Peran Pengawas Internal Terhadap Akuntabilitas Keuangan Dengan Kualitas Laporan Keuangan Sebagai Variabel Intervenin. Laporan Keuangan, 7(2), 82-103.

Supriadi, I. \&. (2020). PENDAMPINGAN KEWIRAUSAHAAN MELALUI IMPLEMENTASI PENYUSUNAN LAPORAN KEUANGAN BERBASIS SAK EMKM PADA UMKM. Laporan Keuangan, 12(2), 168175. 